\title{
Cat Scabies at The Animal Health Clinic of Salatiga Agriculture Service on August to November 2020
}

\author{
${ }^{1)}$ Meta Iqomah, ${ }^{1)}$ Nuraini Suwarno, ${ }^{1)}$ Puji Yuliani \\ ${ }^{1)}$ Salatiga Agriculture Service \\ Corresponding author: metamumuz@gmail.com
}

\begin{abstract}
Scabies is a disease caused mites and zoonotic. Scabies in cats can be caused the mites Sarcoptes scabiei and Notoedres cati. This Study aims to investigate the causes of skin disease and treatment of cats that come to the animal health clinic of Salatiga City Agriculture Service with clinical symptoms similar to scabies. Data collection was carried out from August to November 2020. Confirmation of the diagnosis was done by skin scraping the scab of the earlobe and/ or fingers and observed under a microscope with 1oox magnification. The sticking of skin scrap uses liquid paraffin. The results of the investigation showed that a number of nine cats were positive for scabies with the cause mite is Sarcoptes scabiei. Treatment is done by administering ivermectin injection at a dose of $400 \mathrm{mcg} / \mathrm{kg}$ body weight and diphenhydramine $1 \mathrm{mg} / \mathrm{kg}$ body weight. Of the nine cats, there were three cats that received treatment repetitions up to two times. Without repeated skin scraping, the nine cats recovered with relief of clinical symptoms after treatment.
\end{abstract}

Keywords: scabies, cat, Sarcoptes scabiei, skin scraping, ivermectin, zoonotic

\section{Introduction}

Scabies is caused various types of mites and zoonotic. Mites are arthropods that are included in the Arachnida class, sub-class Acarina, the order Astigmata and the Sarcoptidae family (Pudjiatmoko et al., 2014). Scabies in cats can be caused by the mites Notoedres cati and S. scabiei dan and both can be transmitted to humans. McCarthy et al. (2004) mentioned that the Sarcoptidae family that is capable of transmitting to humans are $S$. scabiei, Notodres cati and Trixacarus caviae. This disease has been knows for a long time. The literature states, scabies was first discovered three thousand years ago and it was called "lice in the flesh" (Alexander, 1984).

Sarcoptes scabiei and $N$. cati are distinguished by their size where $N$. cati has a smaller body size than $S$. scabei. Notoedres' dorsal striations appear like fingerprints of the thumb, short legs and dorsal anus. In contrast to Sarcoptes, which has spines on the dorsal and terminal parts of the anus (Scott et al., 2001; Sofyan et al., 2018). Sarcoptes are characterized by having four pairs of legs in adult mites and three pairs of legs in larval mites. Sarcoptes scabiei lives in the stratum corneum (horn layer) of the skin and feeds on cell fluid. Mites only burrow only the upper layer of the skin and never under the stratum corneum (CDC, 2010). Female mites dig tunnels under the surface of the skin and lay 2-3 eggs every day for 6 consecutive days, causing papules to appear on the skin. The eggs will hatch after 3-4 days (Arlian, 1989; CDC, 2010). The eggs will live as larvae in the tunnels of the skin horn layer. The larvae will leave the tunnel, move to the surface layer of the skin, create lateral channels and hide in hair follicles. Larvae molt within 2-3 days into protonymph and tritonymph which subsequently become adults within 3-6 days (Urquhart et al, 1989; Levine, 1990).

Scaled Pruritus is the main clinical symptom of scabies in cats (Hardy et al, 2016). The symptom that appears when a cat is attacked by scabies is that the cat often scratches its body parts (Susanto et al, 2020). Itching and characterized hair loss with the appearance of the scabs often become the indication of the diagnosis. Confirmation of the diagnosis can be done by skin scraping of the skin that is suspected of being infested with mites. Liquid paraffin or potassium hydroxide can be used for attaching skin scrap to glass objects (Macfarlane, 2014). Both have the following advantages and disadvantages: 
Table 1. Comparison of the Use of Potassium Hydroxide and Liquid Paraffin

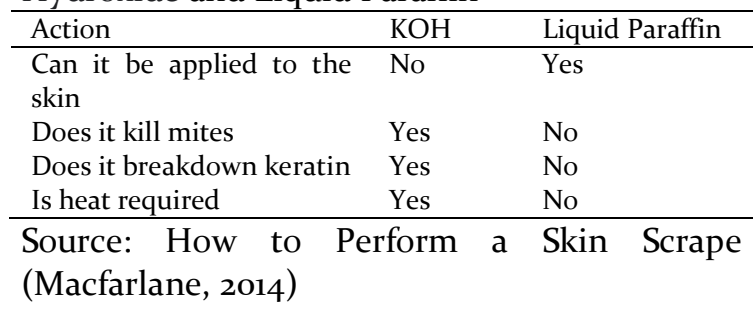

Treatment for scabies can use Ivermectin. Ivermectin is a macrocyclic lactone antibiotic from the Avermectin group, which is derived from the soil-dwelling actinomicetes, Streptomices avermectalis. This drug is widely used for Sarcoptes mites in animals and humans (McCarthy et al., 2004). The dose of Ivermectin for scabies therapy in cats is 400 mcg / kg body weight (Steinbergen, 2019).

The purpose of this study was to investigate the causes of skin disease in cats who came to the animal health clinic of Salatiga Agriculture Service with clinical symptoms similar to scabies.

\section{Methods}

Data were collected from August to November 2020 based on patient arrival through direct observation, animal physical examination, and diagnoses of scabies.

The diagnosis is confirmed by skin scraping examination. The samples taken were skin scrap of the scab on the earlobe and toes. The sample is placed on a glass object, dripped with liquid paraffin and covered with a glass cover and then observed under a microscope with 10ox magnification.

Treatment by giving Ivermectin subcutaneously at a dose of $400 \mathrm{mcg} / \mathrm{kg}$ body weight. To reduce itching, diphenhydramine is given subcutaneously at a dose of $1 \mathrm{mg} / \mathrm{kg}$ body weight.

\section{Results and Discussion}

Data collected during August to November 2020 on 9 (nine) cat patients diagnosed wit scabies with the following information:

Table 2. Data collection results for cat patients diagnosed with scabies at the Animal Health Clinic of Salatiga Agriculture Service in August to November 2020.

\begin{tabular}{|c|c|c|c|c|c|}
\hline No & Date & $\begin{array}{l}\text { Cat } \\
\text { Name }\end{array}$ & Signaling & Clinical Symptom & $\begin{array}{l}\text { Skin scraping } \\
\text { result }\end{array}$ \\
\hline 1 & $\begin{array}{l}10-8- \\
2020\end{array}$ & Caramel & $\begin{array}{l}\text { Persian, male, } 2 \text { years of age, body } \\
\text { weight } 5.6 \mathrm{~kg} \text {, rectal temperature } \\
\text { could not be measured }\end{array}$ & $\begin{array}{l}\text { Scabs on the head and } \\
\text { earlobes more than a } \\
\text { month, erythema on } \\
\text { the back, frequent } \\
\text { scratching }\end{array}$ & (+) Sarcoptes \\
\hline 2 & $\begin{array}{l}25^{-8}- \\
2020\end{array}$ & Chiro & $\begin{array}{l}\text { Persian, male, } 5 \text { months of age, } \\
\text { body weight } 2 \mathrm{~kg} \text {, rectal } \\
\text { temperature } 37.6^{\circ} \mathrm{C}\end{array}$ & $\begin{array}{l}\text { Scabs on the earlobes, } \\
\text { head, and toes }\end{array}$ & (+) Sarcoptes \\
\hline 3 & $\begin{array}{l}28-8- \\
2020\end{array}$ & Liliana & $\begin{array}{l}\text { Persian, female, } 1 \text { year of age, body } \\
\text { weight } 2.8 \mathrm{~kg} \text {, rectal temperature } \\
38.3^{\circ} \mathrm{C}\end{array}$ & $\begin{array}{l}\text { Hair loss, scabs on the } \\
\text { earlobes and toes, } \\
\text { frequent scratching }\end{array}$ & (+) Sarcoptes \\
\hline 4 & $\begin{array}{l}11-9- \\
2020\end{array}$ & Astro & $\begin{array}{l}\text { Persian, female, } 3 \text { years of age, } \\
\text { body weight } 2.8 \mathrm{~kg} \text {, rectal } \\
\text { temperature } 38.7^{\circ} \mathrm{C}\end{array}$ & $\begin{array}{l}\text { scabs on the earlobes, } \\
\text { frequent scratching }\end{array}$ & (+) Sarcoptes \\
\hline 5 & $\begin{array}{l}18-9- \\
2020\end{array}$ & Maiky & $\begin{array}{l}\text { Domestic, male, } 5 \text { months of age, } \\
\text { body weight } 2.4 \mathrm{~kg} \text {, rectal } \\
\text { temperature } 38^{\circ} \mathrm{C}\end{array}$ & $\begin{array}{l}\text { Redness of the face and } \\
\text { earlobe, scabs on the } \\
\text { earlobes }\end{array}$ & (+) Sarcoptes \\
\hline 6 & $\begin{array}{l}15-10^{-} \\
2020\end{array}$ & Monita & $\begin{array}{l}\text { Persian, female, } 6 \text { months of age, } \\
\text { body weight } 2 \mathrm{~kg} \text {, rectal } \\
\text { temperature } 38.9^{\circ} \mathrm{C}\end{array}$ & $\begin{array}{l}\text { scabs on the earlobes, } \\
\text { frequent scratching }\end{array}$ & (+) Sarcoptes \\
\hline 7 & $\begin{array}{l}05^{-11-} \\
2020\end{array}$ & Beti & $\begin{array}{l}\text { Persian, female, } 2 \text { years of age, } \\
\text { body weight } 2.6 \mathrm{~kg} \text {, rectal } \\
\text { temperature } 39.4^{\circ} \mathrm{C}\end{array}$ & $\begin{array}{l}\text { Scabs on the earlobes, } \\
\text { erythema, and hair loss } \\
\text { on the back }\end{array}$ & (+) Sarcoptes \\
\hline 8 & $\begin{array}{l}10-11^{-} \\
2020\end{array}$ & Cici & $\begin{array}{l}\text { Persian, female, } 3 \text { months of age, } \\
\text { body weight } 0.7 \mathrm{~kg} \text {, rectal } \\
\text { temperature } 37.7^{\circ} \mathrm{C}\end{array}$ & $\begin{array}{l}\text { scabs on the earlobes, } \\
\text { frequent scratching }\end{array}$ & (+) Sarcoptes \\
\hline 9 & $\begin{array}{l}17^{-11-} \\
2020\end{array}$ & Jonsun & $\begin{array}{l}\text { Domestic, male, } 1.5 \text { years of age, } \\
\text { body weight } 4 \mathrm{~kg} \text {, rectal } \\
\text { temperature } 37.9^{\circ} \mathrm{C}\end{array}$ & $\begin{array}{l}\text { Scabs on the earlobes, } \\
\text { erythema, and hair loss } \\
\text { on the back, frequent } \\
\text { scratching }\end{array}$ & (+) Sarcoptes \\
\hline
\end{tabular}


Scabies can attack all ages and breeds in both male and female cats. Based on the data obtained, seven of the nine patients were longhaired non-pedigree Persian cats. Their ages varied, four were over one year old and as many as five were the same as and under one year of age. All the cats showed clinical signs of a scab on the earlobe which is characteristic of scabies. Itching is also indicated in almost all cat patients, characterized by frequent scratching of the skin. Howard (2020) reports cats that have scabies due to sarcoptes show symptoms of itching on the skin which has inflammation of the ears, head, and feet. Scabies due to notoedres causes scabbing and hair loss on the ears, head, neck and can spread throughout the body. The notoedres mite is rare and highly contagious in cats and kittens (Grifiin et al, 1993; Sivajothi et al., 2013).

Confirmation of the diagnosis is carried out by skin scraping the crusted skin on the edge of the earlobe. Microscopically examination results showed the findings of mites that cause scabies. Sticking skin scrap using liquid paraffin. The diagnosis of scabies was positive if there were mites, nymphs, larvae, eggs or feces of $S$. scabiei (Fawcett, 2003). On microscopically examination of mites seen alive. The anal terminal is found on microscopic examination. The results of skin scrap showed the presence of sarcoptes mites so that the diagnosis of scabies was given to the nine cats in this study.

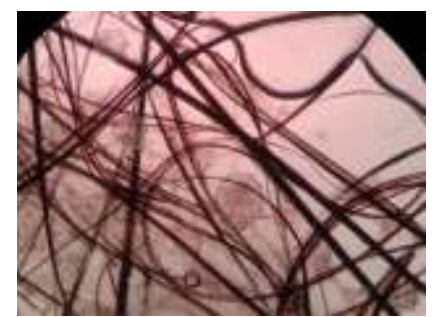

Figure 1. Sarcoptes scabiei on Cici's skin scrap (10ox magnifition)

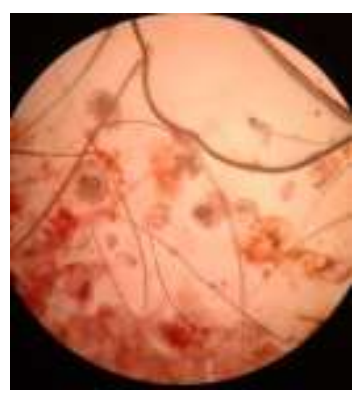

Figure 2. Sarcoptes scabiei on Beti's skin scrap (10ox magnifition)

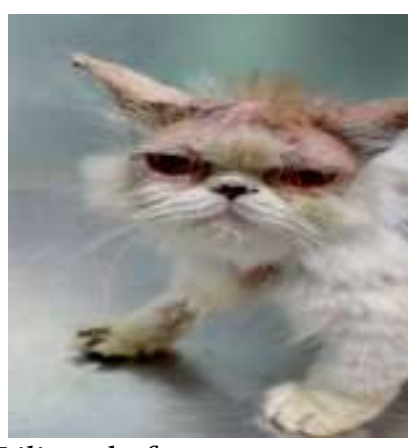

Figure 3. Liliana before treatment: scabs on the earlobes and toes

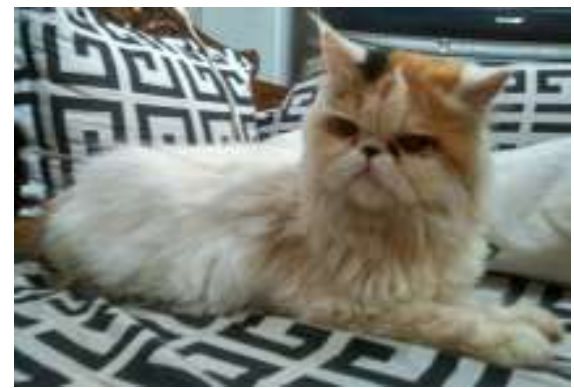

Figure 4. Liliana after treatment: the scab disappears completely and the hair grows back

\section{Conclusions}

The mites that cause scabies in this study were $S$. scabiei. Treatment with ivermectin 400 mcg / kg body weight and diphenhydramine 1 $\mathrm{mg} / \mathrm{kg}$ body weight provide good effectiveness for the treatment of scabies in cats. Skin scraping should be done again after treatment to declare healing.

\section{Acknowledgements}

Thank you to The Salatiga Agriculture Service, especially to the Department of Animal Husbandry and Animal Health.

\section{References}

Alexander JO. 1984. Arthropods and Human Skin. New York: Springer - Verlag. Page. 227-292.

Arlian LG. 1989. Biology, Host Relation, and Epidemiology of Sarcoptes Scabiei. Annual Review of Entomologi.

Barry M, Catharine LK, Barbara BW, Eugene R and Adam JR. 2020. Scabies Medication. https://emedicine.medscape.com/ Accessed on 25 Desember 2020. 
Center for Disease Control and Prevention (CDC). 2010. Parasite-Scabies. https://www.cdc.gov/parasites/scabies/bio logy.html Accessed on 29 November 2020.

Fawcett RS. 2003. Ivermectin Use for Scabies. https://www.aafp.org/ Accessed on 25 Desember 2020.

Griffin C, Kwochka K, and Macdonald. 1993. Current Veterinary Dermatology. Mosby Publications, Linn.

Hardy, JI, G. Sinclair, M. T. Fox, and A. Loeffler. 2016. Feline sarcoptic mange in the UK: a case report. http://veterinaryrecord.bmj.com/ Accessed on 26 November 2020

Howard, B. 2020. How to Identify and Treat Your Cat for Mange. https://www.dailypaws.com/ Accessed on 16 Desember 2020.

Levine, ND. 1990. Text Book of Veterinary Parasitology. Bursess Publishing Company. New York. Page. 325-328

Macfarlane C. 2014. How to Perform a Skin Scrape. Theveterinarynurse.com. UK. Accessed on 26 November 2020.

McCarthy JS, DJ Kemp, SF Walton and BJ Currie. 2004. Scabies : More than just an irritation. $\quad$ www.postgradmedj.com Postgrad Med J Page. 382-387.

N. N. 2016. Sarcoptic Mange. Meravistavet.com. Accessed on 29 November 2020.

Pudjiatmoko, M Syibli, S Nurtanto, N Lubis, Syafrison, S Yulianti, D Kartika, CK Yohana, E Setianingsih, ND Efendi dan E Saudah. 2014. Manual Penyakit Hewan Mamalia. Subdit Pengamatan Penyakit Hewan Direktorat Kesehatan Hewan Direktorat Jenderal Peternakan dan Kesehatan Hewan Kementerian Pertanian. $2^{\text {nd }}$ printing. Page. $438-446$

Scott D, Miller W, Griffin C, Muler, and Kirk. 2001. Small Animal Dermatology. W.B. Sanders Co. Philadelphia, PA.

Sivajothi S, B Sudhakara Reddy, VC Rayulu and C Sreedevi. 2013. Notoedres cati in cats and its management. India. https://www.ncbi.nlm.nih.gov/ Accessed on 28 Desember 2020.

Sofyan MS, MH Susanto, MU Nuha. 2018. Scabiosis (Notoedres cati) in Cat. Proc. of the 2oth FAVA CONGRESS \& The 15th KIVNAS PDHI, Bali Nov 1-3, 2018. Oral Presentation (SA-13). Page. 224-225.

Steinbergen VM. 2019. Toxicology Brief: Proper Use of Ivermectin in Cats. www.vetfolio.com Accessed on 16 Desember 2020.

Susanto H, M Kartikaningrum, RS Wahjuni, SH Warsito, dan MGA. Yuliani. 2020. Kasus Scabies pada Klinik Intermedipet Surabaya. Jurnal Biosains Pascasarjana. Vol. 22 (2020). Sekolah Pascasarjana Universitas Airlangga, Indonesia. Page. 3745 .

Urquhart GM, J Armaur, H Duncan, AM Doon, and FW Jenning. 1989. Veterinary Parasitology . Long Man Scientific and Technical. New York. Page. 191.

Wardhana AH, J Manurung, dan T Iskandar. 2006. Skabies: Tantangan penyakit zoonosis masa kini dan akan datang Balai Penelitian Veteriner. Bogor. Wartazoa 16 (1): 40-52.

Yanuartono S, Indarjulianto, A Nururrozi, S Raharjo, dan H Purnamaningsih. 2020. Penggunaan Antiparasit Ivermectin pada Ternak: Antara Manfaat dan Risiko. Jurnal Sains Peternakan Indonesia. : 112123. 